\title{
COUNTRY FUND DISCOUNTS, ASYMMETRIC \\ INFORMATION AND THE MEXICAN CRISIS \\ OF 1994: DID LOCAL RESIDENTS TURN \\ PESSIMISTIC BEFORE INTERNATIONAL INVESTORS?
}

Jeffrey A. Frankel

Sergio L. Schmukler

Working Paper 5714

\section{NATIONAL BUREAU OF ECONOMIC RESEARCH 1050 Massachusetts Avenue Cambridge, MA 02138 \\ August 1996}

The authors would like to thank Bradford De Long, Carmen Reinhart, Richard Lyons, Maurice Obstfeld, Thomas Rothenberg, and the participants of international finance seminars at the Federal Reserve Board and the NBER Summer Institute for helpful comments and suggestions. We also thank Charles Kramer and R. Todd Smith, of the IMF Research Department, and Donald Cassidy, of Lipper Analytical, for the country fund data. Sergio Schmukler would like to acknowledge support from the Consejo Nacional de Investigaciones Científicas y Técnicas, República Argentina. This paper is part of NBER's research programs in Asset Pricing and International Finance and Macroeconomics. Any opinions expressed are those of the authors and not those of the National Bureau of Economic Research.

(C) 1996 by Jeffrey A. Frankel and Sergio L. Schmukler. All rights reserved. Short sections of text, not to exceed two paragraphs, may be quoted without explicit permission provided that full credit, including $(\mathcal{C}$ notice, is given to the source. 


\title{
COUNTRY FUND DISCOUNTS, ASYMMETRIC INFORMATION AND THE MEXICAN CRISIS OF 1994: DID LOCAL RESIDENTS TURN PESSIMISTIC BEFORE INTERNATIONAL INVESTORS?
}

\begin{abstract}
It has been suggested that Mexican investors were the "front-runners" in the peso crisis of December 1994, turning pessimistic before international investors. Different expectations about their own economy, perhaps due to asymmetric information, prompted Mexican investors to be the first ones to leave the country. This paper uses data from three Mexican country funds to investigate the hypothesis of "divergent expectations." We find that, right before the devaluation, Mexican fund Net Asset Values (mainly driven by Mexican investors) dropped faster than Mexican country fund prices (mainly driven by foreign investors). Moreover, we find that Mexican NAVs tend to Grangercause the country fund prices. This suggests that causality, in some sense, flows from the Mexico City investor community to the Wall Street investor community. More generally, the paper proposes an asymmetric information approach that differs from the existing explanations of country fund discounts.

Jeffrey A. Frankel

Department of Economics

549 Evans Hall

University of California at Berkeley

Berkeley, CA 94720-3880

and NBER

frankel@econ.berkeley.edu

Sergio L. Schmukler

Department of Economics

549 Evans Hall

University of California at Berkeley

Berkeley, CA 94720-3880

sergio@econ.berkeley.edu
\end{abstract}




\section{Introduction}

"The available data show that the pressure on Mexico's foreign exchange reserves during 1994, and in particular just prior to the devaluation, came not from the flight of foreign investors, but from Mexican residents."

- International Capital Markets.

International Monetary Fund, 1995.

"You state that 'the first to flee were not fickle foreign investors but wellinformed Mexicans.' I have yet to see a serious methodology that in effect distinguishes between national and foreign portfolio investors."

Letter to the Editor, The Economist (11/11/95),

Jaime Serra, Former Mexican Finance Minister.

The Mexican crisis in December 1994 posed a question regarding how international financial markets work, among many others. It has been suggested that domestic residents were "closer to information" and thus had better, or at least different, expectations about local economic events in the pre-crisis period. The International 
Monetary Fund (IMF) in its annual Capital Markets Report (1995) expresses the view that "...resident investors in emerging market countries tend to be front-runners in a currency crisis..." (page 7). Under this hypothesis, local investors led the stampede out of Mexican assets in December 1994, much as they had done in the earlier crisis of 1982 (engaging in massive capital flight at a time when U.S. banks were still pouring money into Latin America).

Three Mexican closed-end country funds have been established as vehicles to hold Mexican equities. They are the Mexico Fund (MXF), Mexico Equity and Income Fund (MXE), and Emerging Mexico Fund (MEF). The first one was established in 1981, and the other two in 1990 . They offer a valuable opportunity to study the dynamics of the crisis.

The Net Asset Values (NAVs) of the funds are the aggregate value of the constituency equities, evaluated at local market prices, though translated into U.S. dollars. If markets were perfectly efficient and internationally integrated, then the price of the fund would be equal to the NAV. However this is not the case. We argue that the price of the country fund, which is traded on Wall Street, reflects relatively better the information and expectations held by international investors, while the NAV, which is determined in Mexico City, reflects relatively better the information and expectations held by local investors. In other words, the country fund discount, which is the percentage difference between the two prices, reflects the relative optimism of domestic versus international. A large discount 
indicates that domestic residents have relatively more favorable expectations. A premium indicates that foreigners have relatively more favorable expectations. The present paper focuses on what might variously be called the hypothesis of "divergent sentiments," "heterogeneous expectations," "asymmetric information," and "closer to information."1

Anticipating the most interesting fact in this paper, Figures 1-3 plot Mexican fund prices, NAVs and percentage discounts before the devaluation. They appear to support the claim of the IMF (1995), that Mexican investors were the front-runners in the crisis. The NAVs in Mexico City fell sharply relative to prices in New York in December 1994. In Figure 2, the decline began two weeks before the devaluation. This seems to constitute the sort of evidence of which Jaime Serra questioned the existence in the quote at the head of this paper.

Country funds are ideally suited to help investigate several questions. As a second concern, the crisis also generated new interest in the contagion effects of crises. Although relatively few studies of contagion have been undertaken, Burki and Edwards (1995),

\footnotetext{
' Frankel (1994b, p.254) contained a warning, based on premia in such country fund prices, that a repeat of the 1982 crisis might be coming in Latin America:

"Fluctuations in the premium of the U.S. price of the fund over the net asset value could be a measure of fluctuations in the difference in expectations of U.S. versus local investors. For most of these funds this premium has been higher (or the discount has been lower) during the period 19901992 than during the preceding three years, suggesting bullish sentiment on the part of foreign investors.... Mexico and Brazil show a clearly higher level of relative U.S. investor confidence in the three years from $1990 \ldots$... If our interpretation of the data is correct, that they represent the confidence of U.S. investors relative to local investors, these four graphs suggest a possible replay of the period leading up to 1982, when Latin American residents turned pessimistic regarding their own countries while U.S. banks were still bullish."
}

The same point was made in Frankel (1994a, p.17). 
Calvo and Reinhart (1995), Goldfajn and Valdés (1995) and the IMF (1995) provide empirical and theoretical support on how an exchange rate crisis may have spillover effects on other sectors and on foreign markets. In the present paper we concentrate on the "asymmetric information" hypothesis, while we study contagion in Schmukler and Frankel (1996).

Section II looks at the long-run and short-run relationships between the Mexican fund prices in New York, on the one hand, and the NAVs of their portfolios in Mexico City, on the other. Its purpose is to explain the behavior of discounts in the short run and long run, given the barriers to arbitrage that must exist. Section III explains how the "divergent expectations" hypothesis is a useful complement to the "investor sentiments" and the "loss-aversion" models of country funds suggested by earlier researchers. Beyond the specifics of the Mexican crisis, the section discusses how this hypothesis may justify the existence of average discounts. Empirically, the section investigates whether the evidence is consistent with the "divergent expectations" hypothesis.

\section{Short-Run and Long-Run Behavior of Country Fund Discounts.}

a) Country Fund Discounts. Existing Hypotheses:

A closed-end country fund (hereinafter country fund) consists of a fixed number of shares that are invested in a set of stocks from a particular country. Unlike open-end 
funds, once the fund is established new shares cannot be issued, while existing shares cannot be redeemed. Investors willing to buy or sell country-fund shares need to trade them on secondary security markets. Country funds are traded in New York at their U.S. dollar price. As already noted, if markets were efficient, frictionless, and perfectly integrated internationally, the price of a fund should be equal to its NAV - which is the sum of the U.S. dollar market value of the individual equities at the home country. In practice, however, this is seldom the case. The gaps between prices and NAVs are both large and variable.

It is well known that country funds, as well as domestic closed-end funds, trade at an average discount. Discounts are equal to $\log \left(\mathrm{NAV}_{\mathrm{t}} /\right.$ price $\left._{\mathrm{t}}\right)$. Various papers, such as Hardouvelis, La Porta and Wizman (1994), Diwan, Errunza and Senbet (1993, 1994) and Lee, and Shleifer and Thaler (1991), document that domestic and country fund discounts are large, and also different from zero on average. Several hypotheses have been suggested to explain this phenomenon. Any explanation must include the existence of market frictions that prevent perfect arbitrage. Frictions may be caused by various factors such as transaction costs, illiquidity of assets, capital gains tax liabilities, risks involved in the arbitrage process, and barriers to capital movements.

Lee, Shleifer and Thaler $(1990,1991)$ argue that these factors [while necessary] are not sufficient to explain the "closed-end fund puzzle." The puzzle consists of four elements. First, closed-end funds start out at a premium. Second, after some time the 
premium tends on average to turn into discount. Thereafter, closed-end funds trade at an average discount. Third, discounts fluctuate over time. Fourth, discounts shrink when closed-end funds are terminated through liquidations or open-ending.

Lee, Shleifer and Thaler suggest that the presence of noise traders explains all the elements of the puzzle. ${ }^{2}$ They assume that noise traders are more likely to hold closedend funds. Small investors, with little knowledge, tend to invest through funds and to trade based on sentiments. Therefore, fund prices and discounts vary with their sentiments. Since noise traders make funds riskier, fund prices are on average below the composite price of the underlying assets. NAVs tend to be less influenced by sentiments because each of the constituent equities tends to be closer to its fundamental value. In summary, average discounts exist because of the risk generated in the markets by the interaction between less-than-fully-rational investors (noise traders) and fully-rational investors.

Hardouvelis, La Porta and Wizman (1994) test the "investor sentiment" hypothesis for the case of closed-end country funds. They argue that country funds are a better indicator of investor sentiments than domestic closed-end funds. "Sentiments" here refer to generalized optimistic or pessimistic animal spirits, not based on fundamentals. In the case of holdings of American equities, a change in U.S. investors' sentiments is

\footnotetext{
${ }^{2}$ De Long, Shleiffer, Summers and Waldmann (1990) show that noise traders or irrational investors impose a risk in the price of the asset. Then, even in the absence of fundamental risks, prices can differ from the fundamental values, because of the risk involved in holding the asset.
} 
reflected in both U.S. NAVs and U.S. fund prices. On the other hand, in the case of holdings of emerging market equities, a change in U.S. investors' sentiments is reflected only in country fund prices, and not in their local NAVs (the prices of their underlying assets that are traded in each particular country). In other words, the co-movements of country funds are more likely to reflect U.S. investors' sentiments, since the underlying assets of each of the funds are located in different countries with less common factors. The changes in country fund NAVs more likely reflect changes in each particular market.

Hardouvelis et al. find evidence that the noise trader model is consistent with the existence of country fund discounts. Once cross-border restrictions are taken into account, they find that country funds trade at an average discount. U.S. investors, who mainly set funds' prices, tend to underestimate the fundamental value of the funds. While our interpretation has something in common with Hardouvelis et al., we believe that the fund prices capture U.S. investor sentiment with respect to the country in question, rather than diffuse undifferentiated bullishness.

Kramer and Smith (1995) challenge the investor sentiment hypothesis. Mexican funds and other Latin American funds turned from discounts to premia after the Mexican devaluation in December 1994. They claim that the investor sentiment hypothesis can only justify these premia by suggesting that international investors were optimistic about Latin America after the devaluation. Since optimism at that time seems implausible, they propose an alternative explanation. They hypothesize that the observed premia are 
evidence of loss-averse investors. When fund prices fell after the devaluation, investors did not want to realize paper losses on their closed-end fund shares. They were willing to pay a premium for the country funds, even though they were pessimistic about these funds. They were not willing to sell when prices fell, because the marginal disutility of a loss is relatively high for loss-averse investors. Our response to the Kramer-Smith argument is that the post-crisis premia are consistent with pessimism by foreign investors, provided that Mexican investors turned pessimistic faster.

b) Reconciliation of Hypotheses Regarding Country Fund Discounts:

First, reasoning from the observed fact of wide disparities between prices and NAVs, we infer that arbitrage is not automatic. It is important to realize that in practice it is virtually impossible in this setting to engage in pure (riskless) arbitrage. The following summary sheds some light on why one perhaps should not expect perfect arbitrage. It describes a set of possible "arbitrage" strategies where each one has its own serious limitation. In addition, there exist general limitations to all of the strategies. The chart shows that arbitrage may be not only risky but also sometimes infeasible. Most of these general limitations have been pointed out in previous studies, such as Diwan, Errunza and Senbet (1993), Errunza (1991), and Hardouvelis et al. (1994). 
"Arbitrage" Strategies:

1) Large outside investor could buy entire fund and liquidate.

2) Fund manager could convert to an open-end fund, generating an immediate capital gain to share-holders.

3) Individual investors could buy the fund and sell individual shares short.

4) Individual international investors will have a lower demand for local shares than they would otherwise, and investors will have a higher demand for the country fund than they would otherwise.
Particular Limitations:

1') Requires that investor has a lot of capital, and that the local market is so liquid that large sales do not drive the prices down.

2') It may be difficult to get all of the necessary parties to agree to open-end it. If the manager wanted to deal with fluctuating inflows and redemptions, requiring new investments or liquidations, she would have started an open-end fund in the first place.

3') Short-selling is difficult (or even prohibited) in many of these markets, especially if it means trying simultaneously to sell short a large number of holdings.

4') This factor (like number 3) will indeed put downward pressure on local share prices and upward pressure on country fund prices; but there is no reason to think the influence should be great enough to eliminate the price disparity. 


\section{General Limitations to All Strategies:}

a) Markets may be illiquid. For example, Vanguard (1995) notes that a country's entire market value, or capitalization, may be less than that of a single large U.S. company. In many countries, the shares held by the country funds constitute a large fraction of the shares outstanding. Some shares turn over infrequently.

b) Exchange rate risks are involved, since country funds are traded in U.S. dollars while the individual shares are traded in each country's currency.

c) Markets do not trade at the same time, making simultaneous transactions sometimes infeasible.

d) Transaction costs are larger than in standard U.S. securities markets. For instance, Vanguard estimates that overall transaction costs for buying a basket of emerging market stocks are expected to be over $2 \%$.

e) In some countries there still exist barriers to capital movement.

The series of obstacles to arbitrage imply that expected discounts are different from zero. More properly, the observed fact of these disparities implies that the obstacles must exist. Even though perfect arbitrage is not to be expected, a large enough NAVprice difference should generate some kind of arbitrage. We suggest that discounts fluctuate inside bands before prompting much arbitrage activity. If discounts move below or above the band, rational investors will seek to profit from the NAV-price difference because the expected gains are substantial. 
Given that barriers to arbitrage exist, partially segmenting the markets, the price in Mexico must reflect relatively more closely the asset demands of Mexican residents, and that in New York the demands of foreign residents. It follows that, to whatever extent Mexican investors have different expectations from foreign investors, the country fund discount will to a degree reflect the difference in expectations.

Discounts appear to be mean-reverting. Therefore shocks have larger effects in the short run than in the long run. ${ }^{3}$ Some of the limitations to arbitrage, such as market illiquidity and exchange rate risk, explain the limited speed of mean reversion. Since it takes time to find buyers in local markets for large blocks of stocks, without pushing down the price, the short run may display large gaps. Over a longer horizon, buyers can be found, and discounts shrink. Moreover returns are more uncertain in turbulent periods than in periods of tranquillity, allowing discounts to deviate from their long-run equilibrium level.

The dynamics of discounts can be summed up in the following way. There exists a stationary long-run relationship between each price and its NAV. Given a constant average discount, an innovation in the fund's NAV is expected to be fully transmitted to the fund's price in the long run. On the other hand, a change in a NAV is expected to be only partially transmitted to its price, changing the average short-run discount. In other

\footnotetext{
${ }^{3}$ Tests of stationarity in discounts are reported below, concluding that discounts are mean-reverting processes. Hardouvelis et al. (1993) also find stationary discounts.
} 
words, the short-run elasticity of price with respect to NAV is expected to be less than one, while the long-run elasticity is expected to be close to one.

The existing hypotheses ("investor sentiment" and "loss-aversion") do not explain the complete story. They partly explain the magnitude and persistence of the premia. However, it remains to be understood why NAVs and prices reacted in different ways to the Mexican crisis. These hypotheses do not predict why discounts turned into premia around the time of the Mexican devaluation. This paper argues that different expectations, on the part of Mexican vs. American investors, may be present. The different expectations hypothesis complements the existing explanations. If Mexican investors foresaw the crisis, NAVs fell first and/or fell more rapidly than country fund prices. Therefore, discounts turned into premia even though investors were pessimistic about Mexico.

c) Empirical Testing:

In this subsection we estimate the short-run and long-run relationships between the three Mexican prices and their respective NAVs. ${ }^{4}$ We first determine the stationarity of the series and the long-run relationships from the cointegrating vectors. Then we study the short-run adjustment towards the long-run equilibrium by error-correction models.

\footnotetext{
${ }^{4}$ The funds' descriptions are detailed in Appendix 1, as well as the difference between prices and NAVs.
} 
The relationship between prices and NAVs, as well as that between discounts and exchange rates are analyzed.

Unit root tests, displayed in Part $a$ of Table 1, fail to reject that all prices and NAVs are non-stationary in levels. The null hypothesis tested is that the level of the variables contain a unit root. We perform three unit root tests, Weighted Symmetric, Dickey-Fuller, and Phillips-Perron, to check robustness of the tests. The Weighted Symmetric test tends to have higher power than the Dickey-Fuller one. The PhillipsPerron test calculates a residual variance "robust" to autocorrelation. The numbers of lags used in each case have been determined by the Akaike Information Criterion (AIC). Only the t-statistics for the optimal number of lags are tabulated. The critical values used take into account the finite sample properties. First differences of all the variables yield stationary results although they are not reported.

Even though the levels of the series are non-stationary, there may exist stationary linear combinations of them, called cointegrated vectors. Part $b$ of Table 1 displays unit root tests on discounts, testing whether discounts are stationary. In other words, we restrict the cointegrating vectors to be $(1,-1)$, and perform tests on their residuals. The restrictions are not arbitrary; they are based in hypotheses of how prices are linked to NAVs. Table 1 shows that two out of the three funds reject non-stationarity, according to the Phillips-Perron test. When we include the exogenous dummy variables damexdev and dpolstab, most of the tests yield stationarity. These variables control for events that 
particularly drove the discounts away from their long-run relationships. In some cases non-stationarity cannot be rejected, but these results may be due to not very powerful unit root tests.

The variable dpolstab takes the value 1 the week that NAFTA was approved and the week President Zedillo was elected. It takes the value -1 in the weeks that the markets received bad political and economic news from Mexico, namely when the two political (Colosio and Ruiz-Massieu) assassinations took place, the week of the Chiapas uprising, and the week of the peso devaluation. Otherwise, it contains the value 0 . Therefore, this variable controls for the good news and bad news shocks on the country funds. The variable damexdev takes the value 1 for the six months following the devaluation, otherwise it takes the value 0 .

Table 2 reports the results from cointegration tests. In this case, we do not impose any particular value for the cointegrating vector. (Even though we believe that the constraints are justified on a priori grounds, we go through the cointegration tests because some readers will expect to see them.) The table tabulates the Engle-Granger ${ }^{5}$ and the Johansen-trace $^{6}$ (maximum likelihood) cointegration tests along with the estimated normalized cointegrating vectors. The cointegrating vectors are interpreted as the long-

\footnotetext{
${ }^{5}$ The Engle-Granger cointegration tests is a Dickey-Fuller test on the residuals from the cointegration regression.

The Johansen-trace algorithm tests, in several steps, null hypotheses of $n$ cointegrating vectors against alternative hypotheses of $n+1$ cointegrating vectors.
} 
run relationships between the variables. When no other variables are taken into account, the Johansen test finds one cointegrating relationship for the fund MXF. ${ }^{7}$

We also test the hypothesis that the cointegrating vector between prices and NAVs is $(1,-1)$. We cannot tell that directly from the cointegrating vector, because of the presence of nuisance parameters. Since the residuals are autocorrelated, the fact that there is cointegration is not sufficient to imply that the errors are i.i.d. Normal. As a consequence, we need to correct the statistics so that they are asymptotically Normal. We perform the correction, running two OLS regressions, according to the method of Stock and Watson (1993). The usual t-statistic is multiplied by the first regression's standard error, and divided by the second regression standard error over 1 minus the autocorrelation coefficients. Table 3 shows that two of the three funds cannot reject the hypothesis that the cointegrating vector is $(1,-1)$. A normalized coefficient of 1 implies, as expected, that a change in the NAV is fully transmitted to its price in the long run. A change in fundamentals, which shifts the NAV, ultimately shifts its price by the same magnitude.

Once we have studied the cointegrating vectors, we calculate the speed of adjustment towards the long-run relations. The speed of adjustment determines how much time is necessary for the price to adjust to the long-run relationship with its NAV. In other words, it expresses by how much prices adjust, in the short run, given a departure

\footnotetext{
${ }^{7}$ When other variables are included, the Johansen tests find cointegration for the funds MEF and MXE. In all of the cases it cannot be rejected that only one cointegrating vector exists.
} 
from the long-run equilibrium. Since all the estimated speeds of adjustment are positive, a discrepancy from the long-run equilibrium means an adjustment of the short-run values of prices towards the long-run values.

Tables 4 and 5 display different error-correction models, estimating the speed of adjustment. The adjustment factors have been calculated by a seemingly unrelated regressions (SUR), using the Engle-Granger two-step estimator. ${ }^{9}$ The first step yields super-consistent estimators of the cointegrating vector. Therefore, efficient estimates are obtained in the second step. The lagged residuals from the first step stand for the deviations from the long-run relationships.

Table 4 assumes stationary long-run relationships between prices and NAVs. However we allow the long-run relationships to differ across funds. A SUR is run in the second step, constraining the adjustment factor to be the same for each fund. Assuming that the constraint is valid, the second step yields efficient and unbiased estimators of the error-correction model. The estimated adjustment coefficient is 0.15 per week, and is statistically significant. However, notice that if indeed there is no cointegration, the residuals are non-stationary, making the usual t-tests inappropriate.

\footnotetext{
The closer the speed of adjustment is to zero, the slower the convergence. When the speed of adjustment is equal to 1 , the convergence is instantaneous. Note that the speeds of adjustment are defined as the negative of the coefficients that appear in the tables.

${ }^{9}$ See Banerjee et al. (1994).
} 
The above results show that adjusting to the long-run relationship may take some time, especially in a period when successive shocks occur. These results can also be looked at in a different light. Sudden gaps such as the one that in December 1994 opened up in the Mexican funds may routinely and mechanically reflect the short-run impact of changes in the exchange rate. After all, equities in Mexico City are priced in pesos and the country funds in New York are priced in dollars. Hardouvelis et al. documented that exchange rate changes have such effects on country funds in general. We can isolate the effect associated with the exchange rate per se by estimating the normal relationship between changes in the exchange rate and country fund discounts.

Results from table 5 also show that the Mexican devaluation of 1994 may have been different from other exchange rate changes. It shows that changes in discounts can be only partially explained by changes in the exchange rate. The dummy variable damexdev is negative and statistically significant, explaining the unusual premia observed after the devaluation. In other words, the fall in the discount in December 1994 was greater than would be expected from the magnitude of the devaluation and the usual pattern associated with exchange rate changes. We interpret this as a loss in confidence by Mexican investors (relative to U.S. investors). But, perhaps the most convincing piece of evidence supporting this hypothesis was already evident in Figures 1-3: the change came a few weeks before the devaluation. This supports the hypothesis that the change in discounts was partly due to less optimistic Mexican investors, and not simply to the devaluation itself. 
In the second step, we do not constrain the adjustment coefficients to be the equal to each other, in order to check how different they vary. The results displayed in Table 5 show that the short-run elasticities are not very different from the previous one. It takes some time to go back to the long-run relationships. In this case, the coefficients vary from $13 \%$ to $22 \%$, implying a half life of around 3 to 5 weeks.

In summary, the results show that it takes a few weeks for the short-run variables to fully adjust to the long-run relationships, assuming that no new discrepancies arise. Namely, shocks that drive prices and discounts away from their long-run relationships have only a partial effect in the short run. If no new shocks occur, the prices and discounts adjust at rates ranging from 13 to 22 percent of the gap each week. Since the cointegrating coefficients for NAVs are close to one, a change in a NAV means that its price will change by the same amount in the long run. Even after the initial devaluation, on December 20, the discrepancy remained for several months, suggesting that Mexican residents were more aware than foreigners of the negative implications of the crisis for the Mexican economy.

\section{Were NAVs and Prices Driven by Divergent Expectations?}

a) Average Discounts and Asymmetric Expectations: 
In the previous section we demonstrated mean-reversion in country fund discounts. We also argued that the divergent expectations hypothesis helps explain the premia observed after the devaluation of December 1994. As the IMF capital markets report argued, Mexican investors reacted first to economic and political local events, i.e., the Mexican investors were the front-runners in the devaluation. In the present section we test that divergent expectations drive country fund NAVs and prices throughout the sample period. Moreover, we argue that the asymmetric expectations hypothesis can help to explain the sign of the average discount.

The price of the country fund is observed, on average, to lie below the NAV. Why is this the normal long-run relationship? U.S. investors may be aware that they are less well-informed about emerging market stocks than are the residents of those countries, who are closer to the economies and companies. As a result, U.S. investors have a lower demand for emerging market country assets than do local investors (other things equal). ${ }^{10}$ Since, in our view, the country fund is primarily held by U.S. investors and the local stocks are held relatively more heavily by local investors, the price of the country fund reflects the lower average demand. Furthermore, given the apparent partial segmentation of the country fund market in New York and the corresponding equity markets in Mexico City, movement in the ratio of price to NAV reflects movement in the ratio of U.S.

\footnotetext{
${ }^{10}$ This type of "lemons problem" was originally treated by Akerlof (1970). There is a large literature on asymmetric information in financial markets. One classic reference showing that equity investors will demand a premium to compensate for their informational disadvantage is Myers and Majluf (1984).
} 
investor expectations to local investor expectations. The same discounts, positive on average but variable over time, exist also for other countries.

The ideas of market segmentation and asymmetric information are not new in the country fund literature. Diwan et al. (1993) show that the existence of discounts depends on the nature of market segmentations. Second, Errunza (1991) mentions the existence of different expectations between local and foreign investors. More generally, in reference to the home-country bias that characterizes international investing throughout the securities markets, French and Poterba (1991) say that "They [investors] may impute extra 'risk' to foreign investments because they know less about foreign markets, institutions, and firms." Although these ideas have been present in the literature, we think they became more relevant with the Mexican crisis of 1994.

Several factors may cause expectations to be heterogeneous. First, resident investors may have more access to local news than international investors. If domestic investors are better informed, their expectations will differ from the relatively uninformed international investors. Second, different expectations may arise from the way resident investors read the same information. The same news can be interpreted as different signals by domestic and international investors. Unfortunately, it is not possible to determine what causes expectations to diverge. In particular, there is nothing here to indicate that Mexican residents may have obtained "inside information" illegitimately. Nevertheless, we are able to test for the presence of different expectations. 
First, the variables are plotted against time to observe the reactions of country funds before the devaluation. Second, two econometric approaches are followed. Granger-causality tests are computed to search for causality in the variables. Then, a regression is calculated by SUR to obtain point estimates of how different prices and NAVs are statistically related.

b) Plots, Granger-causality Tests, and SUR:

The plots of the three stocks contain some information about expectations. Figures 1-3 show that both NAVs and prices went up, reflecting more positive expectations from local and foreign investors when markets received good news about Mexico. The two clearest cases are the NAFTA approval in November 1993 and President Zedillo's victory in the presidential election of August 1994. ${ }^{11}$ Country funds are sensitive to changes in sentiments and expectations.

As noted, the figures also show that both prices and NAVs started falling before the devaluation in December 1994. Finally and crucially, the figures provide evidence of divergent expectations before the devaluation. The MXE discount turned into premia a week before the devaluation. In the case of the two other funds, MXF and MEF, both

\footnotetext{
${ }^{11}$ Such political events had a statistically significant effect on Mexican interest rates during the year and a half preceding the crisis, as noted in Frankel and Okongwu (1996).
} 
NAVs and prices fell before the devaluation. However, NAVs fell much more rapidly, showing that discounts started falling sharply before the devaluation.

As a first econometric approach, Granger-causality tests are estimated to determine whether changes in NAVs preceded changes in prices, not just in December 1994, but in general. We run the VAR process in first difference form, since the typical Granger-causality test does not have its standard distribution when the variables are I(1). ${ }^{12}$ Four alternative hypotheses may be tested from these tests: prices Granger-cause NAVs, NAVs Granger-cause prices, neither of them cause the other, or they are simultaneously determined. Table 6 shows the results. ${ }^{13}$ The table and corresponding figure only report the cases where one-direction Granger-causality was found. Figure 4 displays the results in a different way. It indicates the causality relationships with arrows. All three Mexican NAVs Granger-cause one of the three prices in New York. Moreover, both within Mexico and within New York, the biggest Mexican fund, MXF, affects the other funds.

The arrow sizes of Figure 4 have been chosen in an arbitrary but readily-perceived way. The thick arrow indicates that both of two results hold. First, the probability of accepting the null hypothesis of no Granger-causality is less than 5 percent. (More properly, the probability of rejecting the null is higher than 95 percent.) At the same time,

\footnotetext{
12 Schmukler (1996) performs other exogeneity tests, which incorporate cointegrating vectors in the estimation. Those results are very similar to the ones reported here.

${ }^{13}$ Since the Granger-causality test can be very sensitive to the choice of lag length, different specifications have been tried, without substantially changing the results. Only one specification is displayed here.
} 
the thick arrow means that the difference between the probabilities of accepting the null hypothesis is at least of 50 percentage points. In other words, the difference in probability values (P-values) is at least 0.50 , so we are very confident that Granger-causality only goes in one direction, because we accept and reject the null hypotheses strongly. The thin arrow means that the probability of accepting the null hypothesis is less than 5 percent, and that the difference between probabilities is greater than 10 and less than 50 percentage points.

Having tested that causality goes from Mexico to New York, we estimate, as a second econometric approach, a SUR/VAR. In this case, we are interested in how prices are affected by other variables. We report only one representative SUR estimation in Table 7. It shows the contemporaneous relationship between NAVs and prices. The variables are in first differences, to avoid the spurious regression problem and to use Normal limiting distributions. The estimates are calculated by nonlinear least squares, imposing constraints for equal coefficients, but allowing for different constants. The dependent variables are the country fund prices. The independent variables are the fund NAVs, the Mexican exchange rate, the international interest rate, and the dummy for political stability. Under the assumption that the constraints are not too restrictive, the SUR estimation enhances efficiency.

The regression output shows that NAVs are significant in explaining changes in prices, confirming the results obtained with the Granger-causality tests. We also include 
lagged prices, since we found Granger-causality within prices. In this sense the regression displayed in Table 7 is a VAR, with other exogenous variables. The exchange rate is statistically significant and of the right sign. A drop in the value of the peso is reflected as a fall in the value of the underlying assets in terms of dollars. The dummy variable that reflects political stability is also of the right sign, and significant.

The international interest rate is expected to have a negative effect, since a drop in the international interest rate results in an increase in demands and prices for many assets, including Mexican country funds. The regression yields the right sign, although the variable does not turn out to be significant. A negative coefficient for the interest rate agrees with other studies of foreign investor demand in emerging markets more generally, such as Calvo, Leiderman and Reinhart (1993), Chuhan, Claessens and Mamingi (1994), Dooley et al. (1994), Fernandez-Arias (1994), Frankel and Okongwu (1996), and Schadler et al. (1993). 


\section{Summary of Conclusions}

In the present paper we use the three Mexican country funds to show evidence in favor of divergent expectations held by local and foreign investors during the Mexican crisis of December 1994. The asymmetric information hypothesis was suggested in the aftermath of the crisis, implying that Mexican investors reacted before international investors to news about the Mexican economy. This statement can be interpreted in two ways: either domestic and international investors received two different sets of information, or the local investors were more alert and sensitive to potential warning signals.

More generally, we take various elements existent in the literature and formulate a new picture of how country funds behave. Even though indirect arbitrage may exist, it faces several obstacles. We suggest that the nature of these barriers may explain mean reversion, or different reactions of country fund discounts in the short run and in the long run. In turbulent periods, discounts may be large due to market illiquidity or because of increased obstacles to arbitrage. In the long run (in tranquil periods), they tend to be narrower. This hypothesis complements existing models such as the investor-sentiments and the loss-aversion interpretations. We also argue that the presence of heterogeneous expectations explain the persistence of average discounts. 
On the empirical side, Section II showed that although a change in a NAV is fully transmitted to the country fund's price in the long run, it is only partially transmitted in the short run. It also showed that the rates of adjustment towards the long-run relationship, estimated by error-correction models, are around 0.15 per week, depending on the case. They imply that $50 \%$ of the adjustment takes place in around 3 to 5 weeks. A similar estimate was found for the adjustment of discounts, towards their long-run relationship with the exchange rate. A slow rate of convergence plus the divergent expectations hypothesis suggests a reconciliation between the investor sentiment hypothesis and the loss-aversion one.

Section III, presented a new explanation of the observed positive discounts in country funds. If investors indeed have asymmetric information, the presence of positive discounts on average can be reinterpreted. International investors know that they are not so close to information as local investors are. Because of asymmetric information, they are willing to pay less for the same assets.

The empirical part of Section III provided support for the asymmetric expectations hypothesis. It gives as well empirical foundation to our explanation of country fund discounts. The most simple and immediate proof of heterogeneous expectations is in Figures 1-3, which show that NAVs fell first or faster relative to prices right before the devaluation. Granger-causality tests, a SUR/VAR confirm that observation more generally. 
Several extensions of this work are desirable. First, the results could be enriched by a larger data set covering more countries, as well as higher frequency data, if the data can be obtained. Second, there is a need for valid instrumental variables to cope with potential endogeneity. Third, a theoretical model needs to be constructed to flesh out some of the ideas expressed in this paper. 


\section{References}

Akerlof, George, 1970, "The Market for Lemons: Quality Uncertainty and the Market Mechanism," Quarterly Journal of Economics 89:488-500.

Banerjee, Anindya, Juan Dolado, John W. Galbraith, and David F. Hendry, 1994, CoIntegration, Error-Correction, and the Econometric Analysis of Non-Stationary Data, Oxford University Press.

Burki, Shahid Javed and Sebastian Edwards, 1995, "Latin America After Mexico: Quickening the Pace," unpublished manuscript, The World Bank, August.

Calvo, Guillermo, Leonardo Leiderman and Carmen Reinhart, 1993, "Capital Inflows and Real Exchange Rate Appreciation in Latin America: the Role of External Factors," IMF Staff Papers, 40 (1), 108-150.

Calvo, Sara and Carmen Reinhart, 1995, "Capital Flows to Latin America: Is There Evidence of Contagion Effects?," unpublished manuscript, The World Bank International Monetary Fund.

Chuhan, Punam, Stijn Claessens, and Nlandu Mamingi, 1994, "Equity and Bond Flows to Latin America and Asia: the Role of Global and Country," unpublished manuscript, The World Bank.

De Long, J. Bradford, Andrei Shleiffer, Lawrence H. Summers, and Robert Waldmann, 1990, "Noise Trader Risk in Financial Markets," Journal of Political Economy, Vol. 98, no.4, pp. 703-738.

Diwan, Ishac, Vihang Errunza, and Lemma Senbet, 1993, "Country Funds For Emerging Economies," in Stijn Claenssens and Sudarshan Gooptu (eds.) Portfolio Investment in Developing_Countries, Washington: The World Bank.

Diwan, Ishac, Vihang Errunza, and Lemma Senbet, 1994, "Diversification benefits of country funds," in Investing in Emerging Markets, Euromoney Books and The World Bank. 
Dooley, Michael, Eduardo Fernandez-Arias and Kenneth Kletzer, 1994, "Recent Private Capital Inflows to Developing Countries: Is the Debt Crisis History?," National Bureau of Economic Research Working Paper No. 4792, July.

Errunza, Vihang R., 1991, "Pricing of National Index Funds", Review of Quantitative Finance and Accounting, pp. 91-100.

Fernandez-Arias, Eduardo, 1994, "The New Wave of Private Capital Inflows: Push or Pull?," Policy Research Working Paper 1312, Debt and International Finance Division, International Economics Department, The World Bank, June.

Frankel, Jeffrey A., 1994a, "Introduction" to The Internationalization of Equity Markets, the University of Chicago Press, Chicago, 1994.

Frankel, Jeffrey A., 1994b, "Sterilization of Money Inflows: Difficult (Calvo) or Easy (Reisen)?" in Afluencia de Capitales y Estabilizacion en America Latina, edited by Roberto Steiner, Fedesarrollo, Bogota, pp. 241-267.

French, Kenneth and James Poterba, 1991, "Investor Diversification and International Equity Markets," American Economic Review. Papers and Proceedings, May.

Goldfajn, Ilan, and Rodrigo O. Valdés, 1995, "Balance of Payment Crises and Capital Flows: The Role of Liquidity," unpublished manuscript, Massachusetts Institute of Technology.

Hardouvelis, Gikas A., Rafael La Porta, and Thierry A. Wizman, 1994, "What Moves the Discount on Country Equity Funds?," National Bureau of Economic Research Working Paper 4571, in J. Frankel, ed., The Internationalization of Equity Markets, the University of Chicago Press, Chicago.

International Monetary Fund, 1995, International Capital Markets. Developments. Prospects, and Policy Issues, August.

Kramer, Charles, and R. Todd Smith, 1995, "Recent Turmoil in Emerging Markets and the Behavior of Country-Fund Discounts: Removing the Puzzle of the Pricing of 
Closed-End Mutual Funds," International Monetary Fund Working Paper 95/68, July.

Lee, Charles, M.C., Andrei Shleiffer, and Richard Thaler, 1990, "Anomalies. Closed-End Mutual Funds," Journal of economic Perspectives, Vol. 4, No. 4, Fall, pp. 153164. Journal of Finance, Vol. 46, No.1, pp. 75-109.

Myers, S. And N. Majluf, 1984, "Corporate Financing and Investment Decisions When Firms Have Information that Investors Do Not Have," Journal of Financial Economics, pp. 187-221.

Schadler, Susan, Maria Carkovic, Adam Bennett and Robert Kahn, 1993, "Recent Experiences with Surges in Capital Inflows", Occasional Paper 108, International Monetary Fund.

Schmukler, Sergio, 1996, "Country Funds and Asymmetric Information," unpublished manuscript, University of California at Berkeley.

Schmukler, Sergio and Jeffrey Frankel, 1996, "Crisis, Contagion, and Country Funds," unpublished manuscript, University of California at Berkeley.

Stock, James H. and Mark W. Watson, 1993, "A Simple Estimator of Cointegrating. Vectors in Higher Order Integrated Systems," Econometrica 61:783-820.

Vanguard Group, 1995, Plain Talk, “About Investing in Emerging Markets," bulletin. 


\title{
Appendix 1: Closed-end Country Funds
}

The three closed-end funds used are:

\author{
Emerging Mexico Fund (MEF) \\ Mexico Equity \& Income (MXE) \\ Mexican Fund (MXF)
}

Net Asset Values (NAVs) are calculated at the local market close in U.S. dollars. Prices are recorded on the day the NAVs were calculated, usually Fridays.

\section{Appendix 2: Description of Variables and Data ${ }^{14}$}

Country-Funds data have been provided kindly by R. Todd Smith of the International Monetary Fund, Research Department and by Don Cassidy of Lipper Analytical Services. Exchange rate data and Treasury bill rates data have been obtained from Data Stream. The data have weekly frequency and go from $1 / 5 / 90$ to $3 / 8 / 96$.

\section{Variables:}

- mefnavl, mefpricel, mefdisc, mxenavl, mxepricel, mxedisc, mxfnavl, mxfpricel, mxfdisc: Correspond to the Mexican country funds described in Appendix 1. For each country fund, its NAV, price and discount are available. NAVs and prices are all expressed in logarithms, while discounts are differences of logarithms.

- dpolstab: Qualitative variable that reflects political stability in Mexico. Contains $1 \mathrm{~s}$ when President Zedillo was elected and when the NAFTA agreement was approved. Contains 1s when disturbing political events arose in Mexico, i.e. in Colosio and Ruiz-Massieu assassinations, under the Chiapas uprising and when the peso devalued. Contains 0s otherwise.

- damexdev: Is a dummy variable, with 1 for the six months after the Mexican devaluation and 0 otherwise.

- mexerl: Mexican exchange rate in logarithms. Equals the log of the amount of dollars per peso.

- tbill Iml: One-month Treasury bill rate in logarithms.

\footnotetext{
${ }^{14}$ All the modelshave been estimated using the statistical packages Econometric Views and TSP.
} 


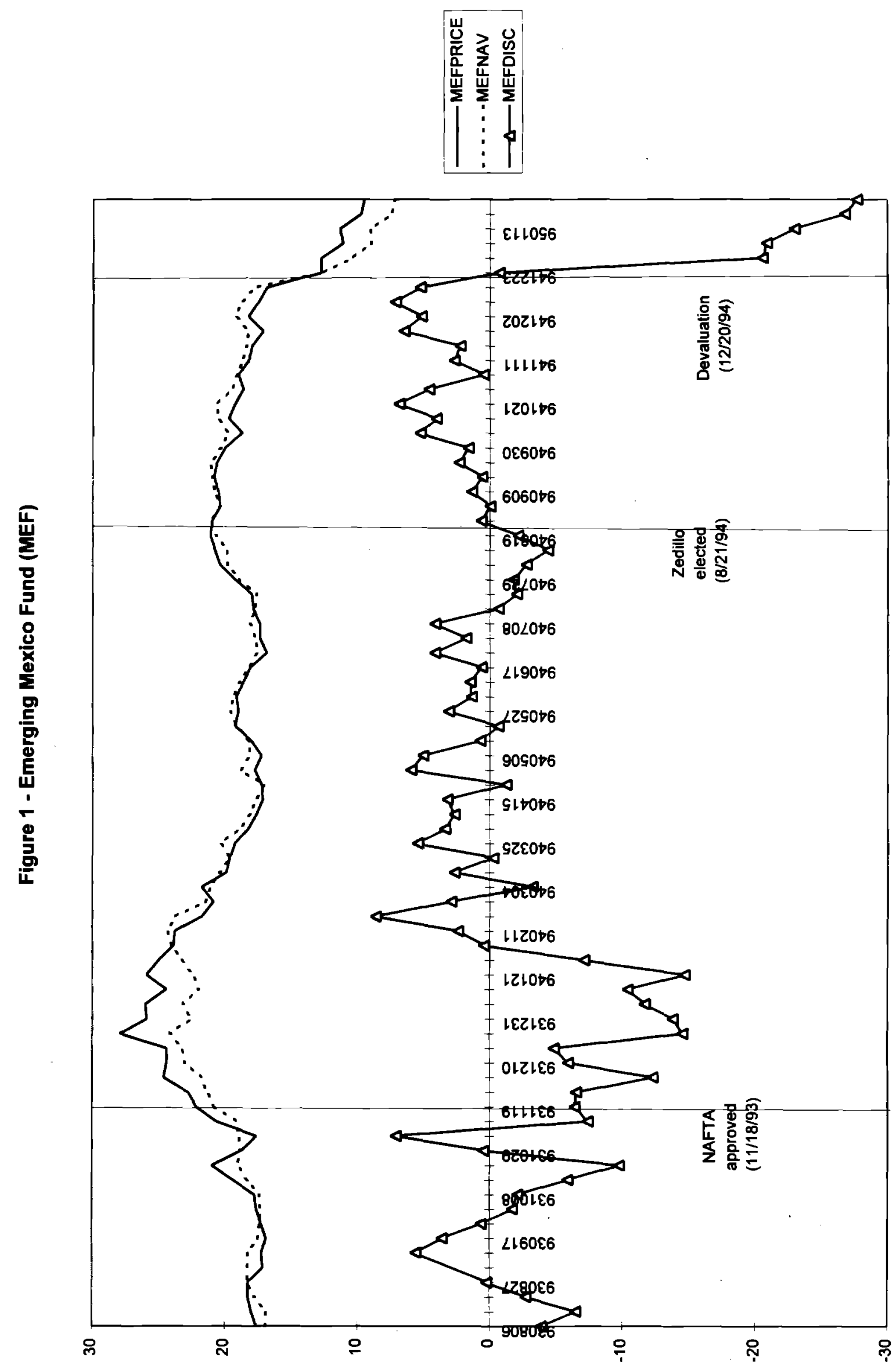



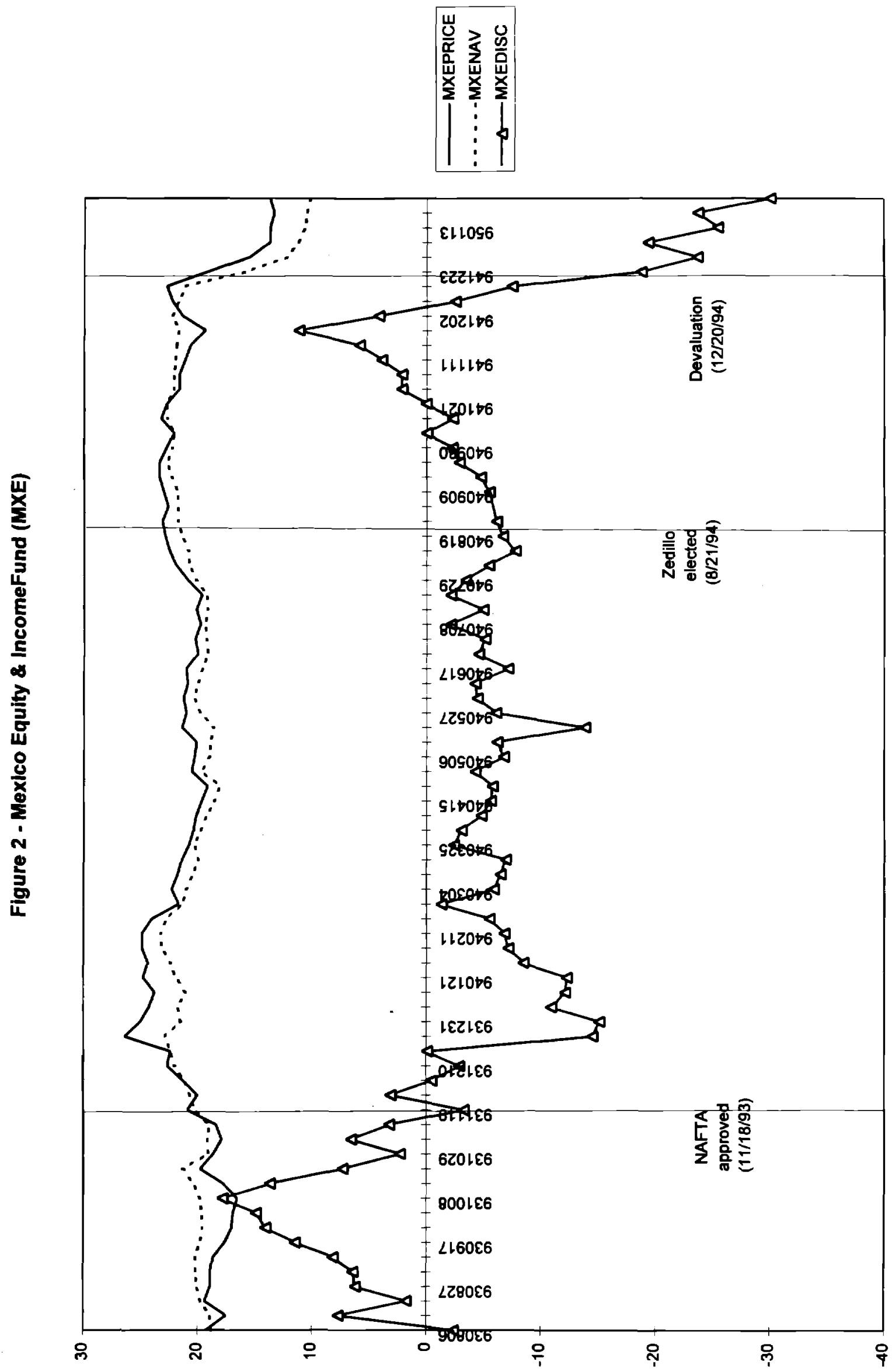

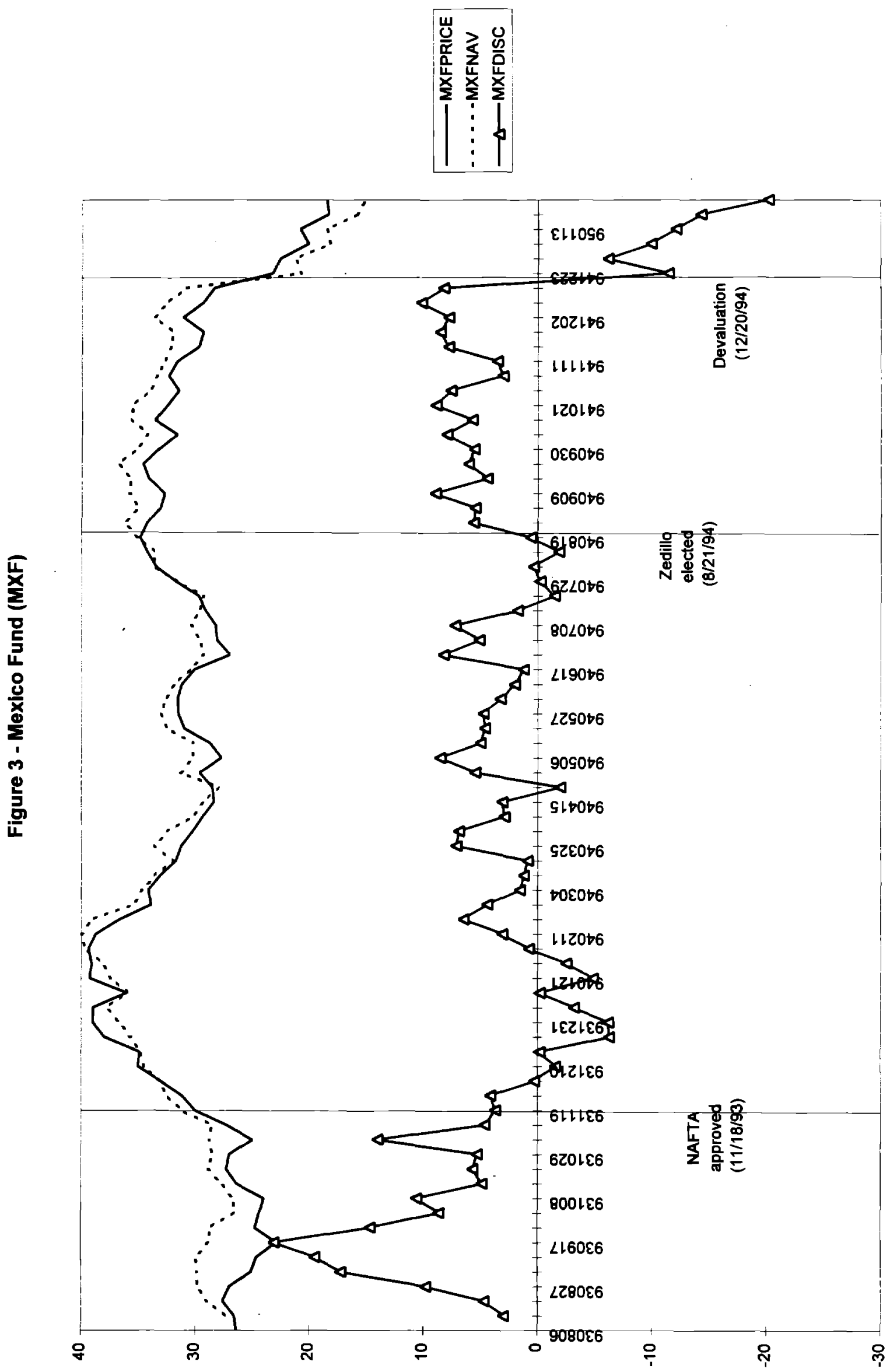
Figure 4: Mexican prices and NAYs
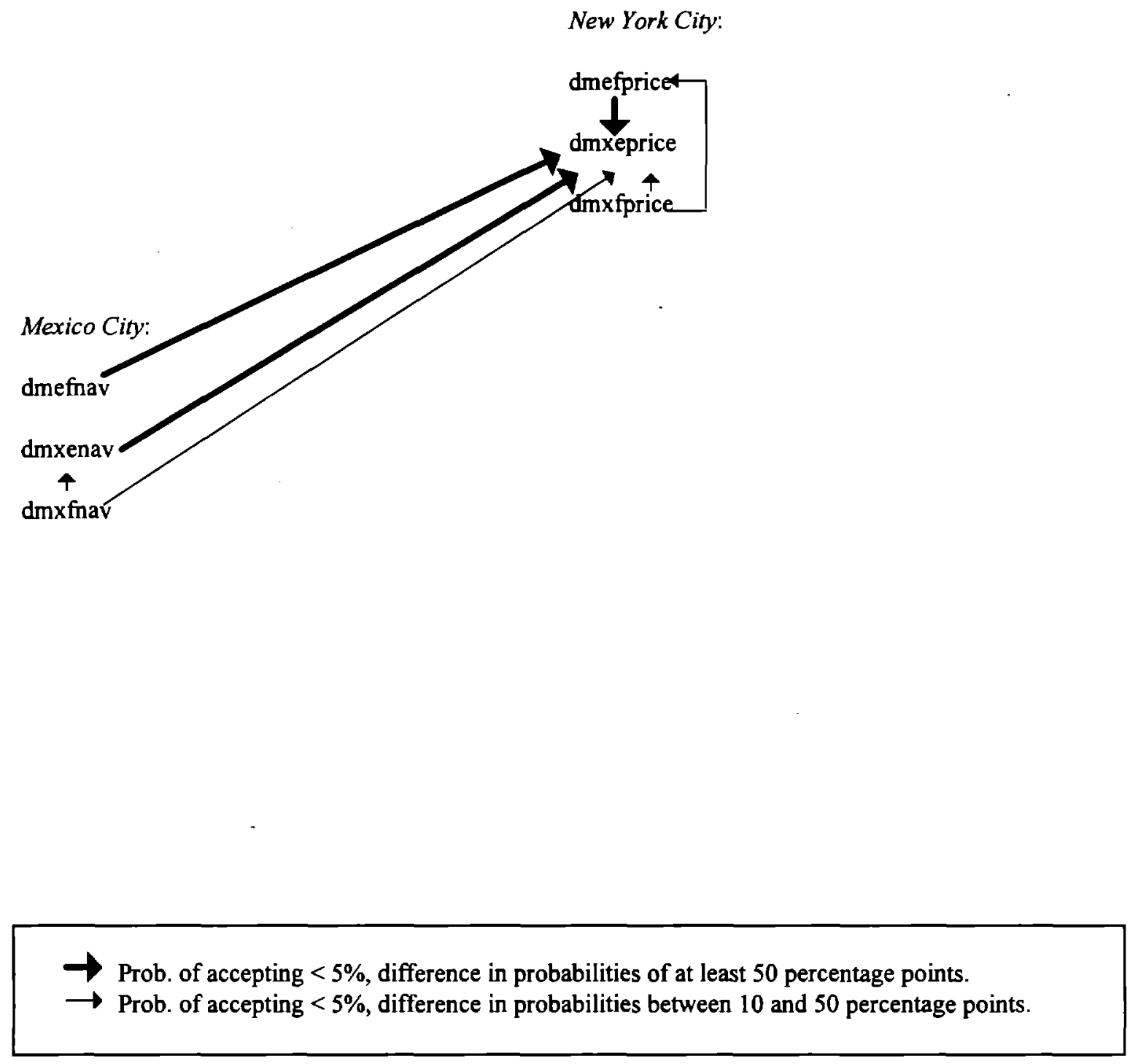
Table 1:

Unit Root Test on Moxican Country Funds

Sample Perlod: 1/5/90 - 3/8/96

a) Unit Root Tests for Moxican NAVs and Prices.

MEFNAVL:

(236 obs.)

MXENAVL:

(236 obs.)

MOFNAVL

(313 obs.)

MEFPRICEL

(236 obs.)

MXEPRICEL

(236 obs.)

MXFPRICEL:

(313 obs.)

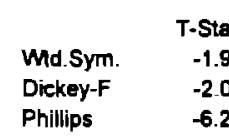

Md.Sym.

Dickey-F Phillips

T-Stat

-1.97
-2.07

$-2.07$

-2.07
-6.22

T-Stat

T-Stat
-1.65

$-1.84$

$-5.21$

Dickey-F

Phillips

T-Stat

T-Stat
-0.98

-0.96
-1.60

-1.60
-4.24

Dickey-F

T-Stat

Wid.Sym

Dickey-F

Phillips

T-Stat
-1.33

-1.33
-1.05

$-3.33$

T-Stat
-1.37

Wd.Sym

Dickey-F

Phillips

$-1.35$

$-4.89$

$\begin{array}{rr}\text { P-value } & \text { Num.lag } \\ 0.67 & 3\end{array}$

0.57

0.73

P-value Num.lag

0.67

0.57

0.73

P-value Num.lag

0.84

0.69

0.81

P-value Num.lag

0.98

0.79

0.87

P-value Num.lag

0.93

0.94

0.92

P-value Num.lag

0.92

0.87

0.83

b) Unit Root Tests for Mexican Dlscounts.

MEFDISCL

(236 obs.)

$\begin{array}{lr} & \text { T-Stat } \\ \text { Md.Sym. } & -2.47\end{array}$

Dickey-F $\quad 0.47$

$\begin{array}{lrrr}\text { Phillips } & -32.96 & -0.47 & 7 \\ & & & \end{array}$

MXEDISCL:

(236 obs.)

T-Stat

Wd.Sym. $\quad-2.50 \quad 0.29 \quad 3$

$\begin{array}{llll}\text { Dickey-F } & -2.27 & 0.45 & 3\end{array}$

Phillips $\quad-18.48$

P-value Num.lags

MXFDISCL:

(313 obs.)

T-Stat P-value Num.lags

$\begin{array}{lrrr}\text { Wd.Sym. } & -2.62 & 0.23 & 6 \\ \text { Dickey-F } & -3.11 & 0.10 & 6\end{array}$

$\begin{array}{llll}\text { Phillips } & -49.68 & -0.00 & 6\end{array}$

The following three groups control for the

exogenous vartables DAMEXDEV and DPOLSTAB.

MEFDISCL

(236 obs.)

$\begin{array}{lrrr} & \text { T-Stat } & \text { P-value } & \text { Num.lags } \\ \text { Wd.Sym. } & -3.23 & 0.04 & 7 \\ \text { Dickey-F } & -3.15 & 0.09 & 7 \\ \text { Phillips } & -87.18 & * 1.45 D-08 & 7\end{array}$

MXEDISCL:

(236 obs.)

$\begin{array}{lrrr} & \text { T-Stat } & \text { P-value } & \text { Num.lags } \\ \text { Md.Sym. } & -3.43 & -0.02 & 3\end{array}$

$\begin{array}{lrrr}\text { Md.Sym. } & -3.43 & -0.02 & 3 \\ \text { Dickey-F } & -3.26 & 0.07 & 3 \\ \text { Phillips } & -43.57 & -0.00 & 3\end{array}$

$-43.57$

MXFDISCL:

(313 obs.)

T-Stat P-value Num.lags

Md.Sym. $\quad-3.09 \quad 0.07 \quad 6$

$\begin{array}{lrrr}\text { Dickey-F } & -3.80 & -0.02 & 6 \\ \text { Phillips } & -77.57 & -1.450-07 & 6\end{array}$

Unit Root Tests Consist of Weighted Symmetric, Augmemted Dickey-Fuller and Phillips-Perron Tests

NAVs: U.S. dollar price of undertying country fund assets

Price : U.S. dollar price of country fund in New York City.

Discount: In(NAV/Price).

( $(-)$ Denotes rejections of the hypothesis at $5 \%(1 \%)$ significance level 
Table 2:

Cointegration Tests Between Mexican Fund Prices and NAVs Sample Period: 1/5/90 - 3/8/96

Dependent variable: MEFPRICEL

Engle-Granger (tau) tests Num lag Opt:8

alpha $\quad 0.91$

TestStat $\quad-2.21$

P-value $\quad 0.42$

Const $\quad 0.34$

t(Const) $\quad 8.83$

Num ob 227.00

LogLike $\quad 360.53$

AIC $\quad-3.10$

Var res $\quad 0.00$
Johansen (trace) tests

Num lag Opt:2

Eigval1 $\quad 0.03$

Eigval2 $\quad 0.00$

HO: $r=0 \quad 8.12$

P-val $\quad 0.61$

HO: $\mathrm{r}<=1 \quad 0.59$

P-val $\quad 0.74$

Num ob 233.00

LogLike $\quad 733.90$

AIC $\quad-6.18$

Cointegrating vect MEFPRI MEFNAVL

$1-0.9477$

Dependent variable: MXEPRICEL

Engle-Granger (tau) tests

Num lag Opt:5

alpha $\quad 0.97$

TestStat $\quad-1.45$

P-value $\quad 0.78$

Const $\quad 1.46$

$\mathrm{t}$ (Const) $\quad 21.36$

Num ob 230.00

LogLike $\quad 390.41$

AIC $\quad-3.34$

Var res $\quad 0.00$
Johansen (trace) tests Num Opt:1

Eigval1 $\quad 0.02$

Eigval2 $\quad 0.01$

HO: $r=0 \quad 7.37$

P-val $\quad 0.68$

HO: $r<=1 \quad 1.89$

P-val- $\quad 0.58$

Num 234.00

LogLike 762.20

AlC $\quad-6.43$

Cointegrating vect MXEPRI MXENAVL

$1-0.5868$

Dependent variable: MXFPRICEL

Engle-Granger (tau) tests

Num lag Opt:6

alpha $\quad 0.91$

TesiStat $\quad \mathbf{- 2 . 5 8}$

P-value $\quad 0.25$

Const $\quad 0.16$

t(Const) $\quad 3.94$

Num ob $\quad 306.00$

LogLike $\quad 527.15$

AIC $\quad-3.40$

Var res $\quad 0.00$
Johansen (trace) tests

Num Opt:2

Eigval1 $\quad 0.06$

Eigval2 $\quad 0.01$

HO:r=0 22.02

P-val " 0.01

HO: $r<=1 \quad 3.90$

P-val $\quad 0.30$

Num $\quad 310.00$

LogLike $\quad 1054.7$

AIC $\quad-6.71$

Cointegrating vect MXFPRI MXFNAVL

$1-0.9906$

"(*) Denotes rejections of the hypothesis at $5 \%(1 \%)$ significance level 
Table 3:

Tests of HO: Cointegrating Vector between Prices and NAVs = [1, -1] *

Sample Period: 1/5/90 - 3/8/96

Equation 1: MEFPRICEL

C

MEFNAVL

DMEFNAVL(+2)

DMEFNAVL(+1)

DMEFNAVL

DMEFNAVL $(-1)$

DMEFNAVL(-2)
Coefficient T-statistic

$0.28 \quad 6.85$

$0.90 \quad 61.35$

$-0.07 \quad-0.55$

$0.10 \quad 0.74$

$-0.05 \quad-0.36$

$-0.14 \quad-1.07$

$-0.07 \quad-0.51$
Corrected T-statistic

Ho: coeff. of MEFNAVL $=1$

$\mathrm{T}($ Stock-Watson $)=\quad-1.58$

Number of observations: 216

Adjusted R-squared $\quad 0.95$

Std. error of regressio $\quad 0.09$

Equation 2: MXEPRICEL

$\begin{array}{lcc}\text { C } & 1.43 & 19.03 \\ \text { MXENAVL } & 0.48 & 17.73 \\ \text { DMXENAVL(+2) } & -0.41 & -1.68 \\ \text { DMXENAVL(+1) } & -0.39 & -1.52 \\ \text { DMXENAVL } & -0.13 & -0.52 \\ \text { DMXENAVL(-1) } & -0.10 & -0.42 \\ \text { DMXENAVL(-2) } & 0.04 & 0.15\end{array}$

Corrected T-statistic

Ho: coeff. of $M X E N A V L=1$

$T($ Stock-Watson $)=$

$-2.27$

Number of observations: 216

$\begin{array}{llll}\text { Adjusted R-squared } & 0.95 & \text { Std. error of regressio } & 0.09\end{array}$

Equation 3: MXFPRICEL

C

MXFNAVL

DMXFNAVL(+2)

DMXFNAVL(+1)

DMXFNAVL

DMXFNAVL(-1)

DMXFNAVL(-2)
Coefficient T-statistic

$\begin{array}{cc}0.11 & 2.55 \\ 0.95 & 65.50 \\ -0.10 & -0.97 \\ 0.17 & 1.65 \\ -0.09 & -0.87 \\ -0.22 & -2.23 \\ -0.23 & -2.28\end{array}$

Number of observations: 270

Adjusted R-squared
Corrected T-statistic

Ho: coeff. of MXFNAVL $=1$

$T($ Stock-Watson $)=\quad-0.91$

- The corrected T-statistics are calculated in a second stage, using the adjustment suggested, among others, by Stock and Watson(1993).

The corrected T-statistic should be compared with the critical values from a $N(0,1)$. 
Table 4:

Error Corroction Modal for Moxican Fund Pricos

Esumated by heratyo Soemingly Unrolatod Regrosslon

Englo-Granger Two Stap Estmator.

Sample Period: 1/5/90 - 3/8/96

First Step:

Coefincient T-Statistic

$\begin{array}{lcc}\text { C(1) } & 0.23 & 7.17 \\ \text { MEFNAVL } & 0.91 & 77.73 \\ \text { C(11) } & 0.21 & 3.68 \\ \text { MXENAVL } & 0.92 & 44.56 \\ \text { C(21) } & 0.16 & 4.40 \\ \text { MXFNAVL } & 0.93 & 78.98\end{array}$

Equation 1: MEFPRICEL

Observations:

Adjusted R-squared

237 S.E. of regression

0.941 Durbin-Watson stat

Equation 2: MXEPRICEL

Observations:

Adjusted R-squared

234 S.E. of regression

0.84 Durbin-Watson stat

Equation 3: MXFPRICEL

Observations: 314 S.E. of rogression

Adjusted R-squared 0.94 Durbin-Walson stat

\section{Second step:}

\begin{tabular}{|lcc}
\hline Second Step: & & \\
& & \\
& & \\
& & \\
& & \\
C(1) & 0.71 icient & T-Statistic \\
RESID1(-1) & 0.00 & -0.32 \\
D(MEFPRICEL(-1))(EQ.1) & -0.15 & -4.68 \\
D(MEFPRICEL(-2))(EQ.1) & -0.25 & -4.04 \\
D(MEFNAVL(-1))(EQ.1) & -0.17 & -2.62 \\
D(MEFNAVL(-2))(EQ.1) & 0.33 & 4.21 \\
C(11) & 0.22 & 2.77 \\
D(MXEPRICEL(-1))(EQ.2) & 0.00 & 0.32 \\
D(MXEPRICEL(-2))(EQ.2) & -0.18 & -2.62 \\
D(MXENAVL(-1))(EQ.2) & -0.02 & -0.30 \\
D(MXENAVL(-2))(EQ.2) & 0.36 & 3.85 \\
C(21) & 0.05 & 0.59 \\
D(MXFPRICEL(-1))(EQ.3) & 0.00 & 0.32 \\
D(MXFPRICEL(-2))(EQ.3) & -0.08 & -1.22 \\
D(MXFNAVL(-1))(EQ.3) & -0.02 & -0.32 \\
D(MXFNAVL(-2))(EQ.3) & 0.07 & 0.97 \\
& 0.15 & 2.25
\end{tabular}

Equation 1: D(MEFPRICEL)

0.08

0.35
Observations: $\quad 22$

228 S.E. of regression Durbin-Watson stat

0.06

1.75

Equation 2: D(MXEPRICEL)

$\begin{array}{llll}\text { Observations: } & 221 & \text { S.E. of regression } & 0.06\end{array}$

Adjusted R-squared $\quad 0.10 \quad$ Durbin-Watson stat 2.02

Equation 3: D(MXFPRICEL)

Observations: $\quad 294$ 
Table 5:

Error Correttion Model for Moxiean Fund Discounts

Estimated by herativo Seemingly Unrolated Regression

Engle-Gringer Two Step Estimator

Semple Period: 1/5/90 - 3/8/96

First Step:

Estimation Method: Seemingly Unrelated Regression

C(1)

DMEXERL(EQ.1)

DAMEXDEV

$C(11)$

DMEXERL(EQ.2)

$C(21)$

DMEXERL(EQ.3)

$\begin{array}{cc}\text { Coefficient } & \text { T-Statistlc } \\ 2.55 & 5.16 \\ 39.09 & 1.91 \\ -21.76 & -18.46 \\ 3.84 & 7.52 \\ -23.77 & -1.16 \\ 7.79 & 21.13 \\ 1.59 & 0.09\end{array}$

Equation 1: MEFDISCL

Adjusted R-squared

237 S.E. of regression

7.74

0.53 Durbin-Watson stat

0.51

Equation 2: MXEDISCL

Observations:

234 S.E. of regression 7.94

Adjusted R-squared

0.51 Durbin-Watson stat

0.42

Equation 3: MXFDISCL

Observalions:

314 S.E. of regression

0.37 Durbin-Watson stat

Adjusted R-squared

6.59

0.56
Second Step:

Estimabion Mothod: Seemingly Unrelaled Regression

C(1)

RESID1(-1)

D(MEFDISCL(-1))

D(MEFDISCL(-2))

Coefricient T-Statistic

$0.40 \quad 1.30$

$-0.21 \quad-5.25$

$-0.28 \quad-4.48$

D(MEXERL(-2))(EQ 1) $\quad-12.67 \quad-0.94$

C(11)

RESID2(-1)

$0.11 \quad 0.36$

D(MXEDISCL(-1)) $\quad-0.26 \quad-3.86$

D(MXEDISCL(-2)) $\quad-0.06 \quad-0.88$

D(MEXERL(-1))(EQ.2) $\quad-16.51 \quad-1.39$

D(MEXERL(-2))(EQ.2) $\quad-9.00 \quad-0.77$

C(21)

RESID3(-1)

-0.77
0.40

$-0.22-5.63$

$\quad-0.20 \quad-3.58$

D(MXFDISCL(-2)) $\quad-0.02 \quad-0.35$

D(MEXERL(-1))(EQ.3) $\quad-19.57 \quad-1.69$

D(MEXERL(-2))(EQ.3) $3.20 \quad 0.28$
Equation 1: D(MEFDISCL)

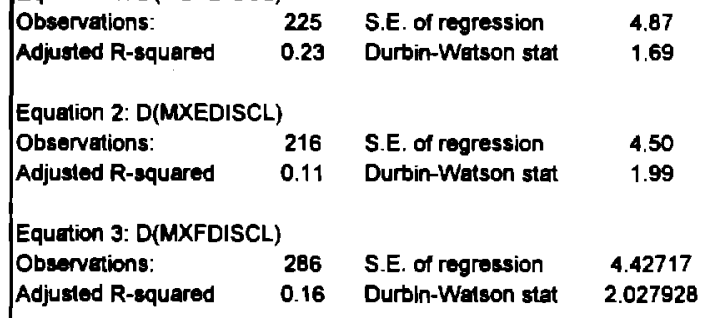


Table 6: Pairwise Granger Causality Tests

Between First Difference of Mexican Fund Prices and NAVs (2 lags)

Sample Period: 1/5/90 - 3/8/96

Null Hypothesis

Obs F-St. Prob.

DMXEPRICEL does not Granger Cause DMEFNAVL

DMEFNAVL does not Granger Cause DMXEPRICEL

225

$0.12 \quad 0.89$

$11.13 \quad 0.00$

DMXEPRICEL does not Granger Cause DMEFPRICE

DMEFPRICEL does not Granger Cause DMXEPRICEL

281

$0.20 \quad 0.82$

$17.42 \quad 0.00$

DMXFPRICEL does not Granger Cause DMEFPRICE

$4.88 \quad 0.01$

DMEFPRICEL does not Granger Cause DMXFPRICEL

$0.75 \quad 0.47$

DMXEPRICEL does not Granger Cause DMXENAVL DMXENAVL does not Granger Cause DMXEPRICEL

DMXFNAVL does not Granger Cause DMXENAVL DMXENAVL does not Granger Cause DMXFNAVL

DMXFNAVL does not Granger Cause DMXEPRICEL DMXEPRICEL does not Granger Cause DMXFNAVL 
Table 7:

Iterative Seemingly Unrelated Regression Convergence achieved after 6 iterations Sample Period: 1/5/90 - 3/8/96

$$
\text { Coefficient T-Statistic }
$$

$\begin{array}{lcc}\text { C(EQ.1) } & 0.00 & 0.03 \\ \text { C(EQ.2) } & 0.00 & 0.49 \\ \text { C(EQ.3) } & 0.00 & 0.47 \\ \text { DMEFNAVL } & 0.34 & 2.83 \\ \text { DMXENAVL } & 0.19 & 1.84 \\ \text { DMXFNAVL } & 0.35 & 3.83 \\ \text { DMEXERL } & 0.32 & 2.35 \\ \text { DTBILL1ML } & -0.04 & -1.22 \\ \text { DPOLSTAB } & 0.03 & 2.32 \\ \text { DMEFPRICEL(-1) } & 0.14 & 2.05 \\ \text { DMXEPRICEL(-1) } & -0.17 & -2.51 \\ \text { DMXFPRICEL(-1) } & -0.14 & -1.84 \\ \text { DMEFPRICEL(-2) } & 0.00 & 0.04 \\ \text { DMXEPRICEL(-2) } & -0.06 & -0.93 \\ \text { DMXFPRICEL(-2) } & 0.05 & 0.67\end{array}$

Equation 1: DMEFPRICEL Observations: 205 Adjusted R-squared $\quad 0.28$

Equation 2: DMXEPRICEL Observations: 205 205 S.E. of regression $\quad 0.04$ $\begin{array}{llll}\text { Adjusted R-squared } \quad 0.49 \quad \text { Durbin-Watson stat } & 1.95\end{array}$

Equation 3: DMXFNAVL Observations: 